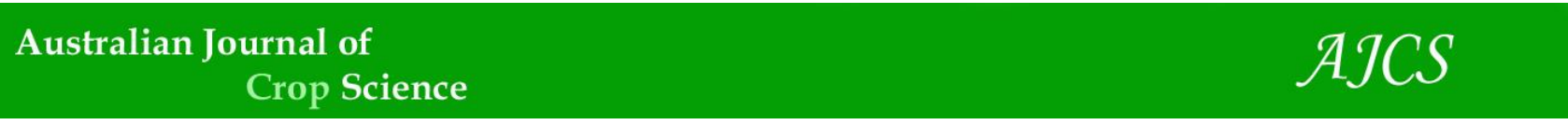

AJCS 13(08):1327-1334 (2019)

ISSN:1835-2707

doi: 10.21475/ajcs.19.13.08.p1739

\title{
Effects of soil temperature and moisture on biological nitrogen fixation in soybean crop
}

\author{
Evandro Ademir Deak, Thomas Newton Martin*, Glauber Monçon Fipke, Jessica Deolinda Leivas Stecca, \\ Luciane Almeri Tabaldi, Ubirajara Russi Nunes, José Eduardo Minussi Winck, Luiz Fernando Teleken \\ Grando
}

Department of Crop science, Universidade Federal de Santa Maria, Santa Maria, RS, Brazil

\section{*Corresponding author: martin.ufsm@gmail.com}

\begin{abstract}
Soil temperature and humidity are the chief determinants for good nodule formation at the time of sowing and emergence. The aim of this study was to estimate the soil temperature and humidity range, at which the Bradyrhizobium spp., and Azospirillum brasilense may have the highest effect on root enhancement and development of nodulation in soybean. Two experiments were conducted, the first of which was done in the seed laboratory performing the treatments listed as non-inoculated; inoculation with Bradyrhizobium; root enhancers; inoculation with Bradyrhizobium + root enhancers; co-inoculation with Bradyrhizobium + Azospirillum brasilense; co-inoculation with Bradyrhizobium + Azospirillum brasilense + root enhancers, and assessed at temperatures of $15,20,25,30$ and $35 \circ \mathrm{C}$. The experimental design was completely randomized with distribution in a factorial. The second experiment was executed in a greenhouse, employing the same treatments affected in the seed laboratory experiment, but with the addition of non-inoculated control with mineral nitrogen. Tests were done at the soil moisture levels of 25, 50, 75 and $100 \%$ water retention capacity, forming a factorial $7 \times 4$ (only second experiment). All co-inoculated treatments induced the soybean root system to improve, in terms of length, volume, surface area and root diameter, exhibiting superiority to the uninoculated control in the 20 to $30 \circ \mathrm{C}$ temperature range. The co-inoculation raised nodulation in the soybean crop, when soil water retention capacity was at the range of $56-96 \%$, achieving higher means compared to the standard inoculation. The root planter added no improvement to either the root system or nodulation in soybean.
\end{abstract}

Keywords: Inoculation; co-inoculation; Bradyrhizobium spp; Azospirillum spp; nodulation.

Abbreviations: $A$. brasilense_Azospirillum brasilense; $\mathrm{N}_{2}$ atmospheric nitrogen; BNF_biological nitrogen fixation; $F C$ first count; LSD_least significant difference; PGPB_plant growth promoting bacteria; NI_non inoculation; [I (Brady)]_inoculation with Bradyrhizobium; R_root enhancers; I+R_inoculation with Bradyrhizobium root enhancers; I+Azo_co-inoculation with Bradyrhizobium + Azospirillum brasilense; I+Azo+R_co-inoculation with Bradyrhizobium + Azospirillum brasilense + root enhancers; First count (A), G_percentage of germination; SL_shoot length; RL_root length; TRL_total root length; RSA_root surface area; DR_root diameter; RV_root volume; NN_Number of nodules; NDM_nodule dry mass; SDM_shoot dry mass; RDM_root dry mass. NFB_nitrogen fixing bacteria.

Introduction

The soybean crop needs roughly $78 \mathrm{~kg}$ of nitrogen $(\mathrm{N})$ for every ton of grain yield (Prado, 2008). This nutrient is provided mainly by the action of the nitrogen fixing bacteria (NFB) (Hungria et al., 2007). This nitrogenous complex present in the root nodules converts the atmospheric nitrogen $\left(\mathrm{N}_{2}\right)$ into assimilates that the plants can easily absorb, thus circumventing the expenditure for nitrogen fertilizers (Ormeño-Orrillo et al., 2013). Co-inoculation in the soybean crop occurs during the inoculation process due to inoculation with bacteria belonging to genus Bradyrhizobium spp., in association with Azospirillum brasilense ( $A$. brasilense) (Cerezini et al., 2016; Hungria et al., 2013). The $A$. brasilense are the plant growth promoting bacteria (PGPB) found to colonize the rhizosphere (Kloepper and Schroth, 1978). The PGPB induce plants to generate the plant growth hormones, like the auxins, gibberellins, cytokinins and ethylene (Tien et al., 1979). In turn, it activates shoot growth and lateral root emission (Ferlini, 2006), as well as raise plant resistance to diseases (Wang et al., 2009), solubilization of phosphates (Rodriguez et al., 2004) and fixation of environmental nitrogen (Ashraf et al., 2011). Environments characterized by low water availability and high temperatures cause a drop in the biological nitrogen fixation (BNF) (Zullu Junior et al., 2008). This fact must be aggravated in the next 70 to 100 years as the global temperature rises by 4 으 as predicted (CLINE, 2007). Soil temperature also disturbs the fixation processes, as it can cross $40 \circ \mathrm{C}$ at $5 \mathrm{~cm}$ depth, imposing limitations on the BNF and nodule viability in the soil (Hungria and Vargas, 2000). The soybean crop thrives under favorable temperatures from 25 to 30 으, 
during its developmental stages in the soil. In legumes, the optimal temperature for induction of BNF ranges from 27 to $40^{\circ} \mathrm{C}$, although temperatures exceeding $37^{\circ} \mathrm{C}$ cause the death of the rhizobia and some genetic changes, rendering them less efficient, when compared with the selected strains (Hungria and Stacey, 1997). The low soil moisture affects the bacteria based on the intensity, duration and developmental stage of the plants, causing greater damage to the initiation of symbiosis and nodule formation in the V2 stage, during full bloom (R2) and grain filling (R5) (Christophe et al., 2011; Fehr and Cavines, 1977; González-Dugo et al., 2010). Coinoculation of Bradyrhizobium with $A$. brasilense may prove to be a suitable alternative that will minimize the influence of high temperatures and low soil moisture, which may boost the nodule formation and BNF (Hungria et al., 2015). Besides, the addition of rotifers (nutrients, hormones) may eventually be a viable substitute, as it encourages cell division, elongation and differentiation, supporting water and nutrient absorption (Silva et al., 2008). Therefore, measures that alleviate these issues are required to control the problems caused by soil temperature and humidity, and maintain the process efficiency.

This study aimed at estimating the soil temperature and humidity range, in which the Bradyrhizobium spp., $A$. brasilense and a root enhancers can offer the greatest support for the growth and nodulation of the root system in soybean.

\section{Results and discussion}

\section{Experiment 1 - Seed laboratory}

In the first count $(\mathrm{FC})$ test, the uninoculated control revealed the highest percentage, while the treatment with $I+R$ showed the lowest averages. It was the sole treatment with the least significant difference (LSD) and it differed from the uninoculated control in the 19 to $33^{\circ} \mathrm{C}$ range, and at $26 \% \mathrm{C}$, where the best performance was recorded. The control was $11 \%$ higher (Figure 1A). Bulegon et al. (2014) reported a lower mean FC value for the Apolo and Turbo cultivars when co-inoculation was employed, confirming the difference between the cultivars in terms of the seed inoculation and germination, likely because of the genetic factors, vigor and amount of accumulated reserves. The slower developmental rate of those seedlings that were inoculated and particularly the root enhancers may be linked to the toxic influence exerted by the nutrients present in this product with the seeds (Plazinsk and Rolfe, 1985).

When the Bradyrhizobium spp., A. brasilense and root enhancers were used, the germination (G) of the seedlings remained unaffected. Inoculation was observed to normally affect the development only from the time of germination of the plants (Zilli et al., 2006). The highest $G$ value was noted at $25^{\circ} \mathrm{C}$, at which $93 \%$ seed germination was observed (Smith, 1995). At temperatures of 15 and $35^{\circ} \mathrm{C}$ the plants did not emit secondary roots and were not accounted in germination test." (Fig 1B). The lack of any impact by the inoculation on germination may be possibly due to the physiological process of the hormones and nutrients present within the seeds being naturally released (Taiz and Zieger, 2013). Brazilian legislation stipulates $80 \%$ as the minimum germination percentage for soybean seed production, and values higher than this were achieved in the 22 to $28{ }^{\circ} \mathrm{C}$ range. This demonstrates that quality soil management is crucial in maintaining soil temperature at the time of sowing, to achieve desirable plant population.

The co-inoculation with Bradyrhizobium + Azospirillum brasilense + root enhancers $(1+A z O+R)$ treatment showed $4 \%$ higher value for shoot length (SL), when compared with the standard inoculation at the $25 \circ \mathrm{C}$. This encouraged greater plant development with 8.9 for $\mathrm{I}+\mathrm{AzO}+\mathrm{R}$ and $8.5 \mathrm{~cm}$ for noninoculated (NI) (Figure 1C). This result was likely due to the stimuli for plant hormone production supported by the bacteria, which favored lateral root emission and taller shoot growth (Crozier et al., 1988).

Considering root length, the co-inoculation with Bradyrhizobium + Azospirillum brasilense (I+Azo) treatment was observed as best among the treatments, even better than the $\mathrm{NI}$ treatment in the 20 to $25 \circ \mathrm{C}$ range. The maximum technical efficiency (MTE) was achieved at $25 \circ \mathrm{C}$ with a value of $15.6 \mathrm{~cm}$, while NI was $13.5 \mathrm{~cm}$, implying that the co-inoculation boosted the root length RL by $15 \%$ (Figure 1D). The higher initial growth displayed by the seedlings signifies their ability to intercept more sunlight and thus perform increased photosynthesis. The improvement in the root system raises the water and nutrient absorbing efficiency of the plant, as well as enables it to tide over conditions of low water availability and higher competitiveness against the weeds.

Root scanning confirmed that the co-inoculated treatment I+Azo ensured higher means for the total root length (TRL). In fact, this treatment revealed means that were statistically higher than NIs between 17 and $31^{\circ} \mathrm{C}$ (Figure 1E, Supplementary Figure 1). When the root enhancers were applied along with the co-inoculation, the TRL was decreased, indicating that this product contains micronutrients combined with the inoculation and coinoculation of seeds. It can result in the death of the bacteria, as the saline formulations and low $\mathrm{pH}$ reduce the nodulation and BNF (Bárbaro et al., 2009). The longest root length $(37 \mathrm{~cm})$ in the co-inoculated treatment was observed at $25 \circ \mathrm{C}$, which was $33 \%$ higher than the control $(28 \mathrm{~cm})$. Besides, with respect to the temperature range, the coinoculated treatment was seen to achieve $28 \mathrm{~cm}$ even at $20 \circ \mathrm{C}$ temperature, staying well above this length until $30 \circ \mathrm{C}$ was reached. Thus one can prove that a wide temperature range can produce positive results. Regarding the standard inoculation with a mean of $29 \mathrm{~cm}$ at $25 \circ \mathrm{C}$, a gain of $27 \%$ was achieved. The root surface area (RSA) and volume demonstrated the highest means for the treatment that involved co-inoculation without employing root enhancers (Figures $1 \mathrm{~F}, \mathrm{H}$ ).

The increased number of lateral roots, root hair density and its consequences, promote root infection by Bradyrhizobium, improving the BNF. This occurs due to the rise in the Nod gene production in response to the inoculation with Azospirillum (Burdmann et al., 2000).

For the root diameter (RD) factor, the lowest diameters were identified in the treatments with temperatures about 25ㅇ $\mathrm{C}$ (Figure 1G). The I+Azo treatment revealed the lowest averages, particularly in the 20 to $30^{\circ} \mathrm{C}$ range, because this treatment supported the higher root emission.; however, as these new roots have a smaller diameter, the average root diameter is reduced. The production of new roots is beneficial for the BNF because they are more susceptible to the bacteria-induced infection. The availability of more 
Table 1. Equations for the values of first count, germination, shoot length, root length, total root length, root surface area, root diameter and root volume adjustment, according to different inoculations and temperatures $15,20,30$ and $35^{\circ} \mathrm{C}$. Santa Maria, RS, Brazil.

\begin{tabular}{|c|c|c|c|}
\hline Treatment & Equation & $r^{2}$ & $p \leq 0.05$ \\
\hline \multicolumn{4}{|c|}{ First count (\%) } \\
\hline $\mathrm{NI}$ & $\mathrm{FC}=-330.228571+29.588571 \mathrm{~T}-0.568571 \mathrm{~T}^{2}$ & 0.62 & 0.00 \\
\hline I (Brady) & $F C=-329.371429+29.611429 T-0.571429 T^{2}$ & 0.62 & 0.00 \\
\hline $\mathrm{R}$ & $\mathrm{FC}=-322.400000+29.000000 \mathrm{~T}-0.560000 \mathrm{~T}^{2}$ & 0.62 & 0.00 \\
\hline $\mathrm{I}+\mathrm{R}$ & $F C=-266.000000+23.880000 T-0.460000 T^{2}$ & 0.62 & 0.00 \\
\hline I+Azo & $F C=-299.257143+26.857143 T-0.517143 T^{2}$ & 0.62 & 0.00 \\
\hline $\mathrm{I}+\mathrm{Azo}+\mathrm{R}$ & $F C=-310.857143+27.897143 T-0.537143 T^{2}$ & 0.62 & 0.00 \\
\hline \multicolumn{4}{|c|}{ Germination (\%) } \\
\hline Temperature & $\mathrm{G}=-484.778571+46.171905 \mathrm{~T}-0.921905 \mathrm{~T}^{2}$ & 0.98 & 0.01 \\
\hline \multicolumn{4}{|c|}{ Shoot length $\left(\mathrm{cm}^{-1}\right)$} \\
\hline $\mathrm{NI}$ & $S L=-29.268500+2.981850 \mathrm{~T}-0.058750 \mathrm{~T}^{2}$ & 0.98 & 0.00 \\
\hline I (Brady) & $S L=-23.825714+2.410564 T-0.046164 T^{2}$ & 0.93 & 0.00 \\
\hline $\mathrm{R}$ & $S L=-27.445000+2.802100 T-0.055700 T^{2}$ & 0.97 & 0.00 \\
\hline $\mathrm{I}+\mathrm{R}$ & $S L=-28.119357+2.875007 T-0.056707 T^{2}$ & 0.97 & 0.00 \\
\hline I+Azo & $S L=-23.734643+2.474493 T-0.047493 T^{2}$ & 0.89 & 0.00 \\
\hline $\mathrm{I}+\mathrm{Azo}+\mathrm{R}$ & $S L=-26.263571+2.714021 T-0.052321 T^{2}$ & 0.91 & 0.00 \\
\hline \multicolumn{4}{|c|}{ Root length $\left(\mathrm{cm}^{-1}\right)$} \\
\hline $\mathrm{NI}$ & $R L=-54.587214+5.540064 T-0.110964 T^{2}$ & 0.91 & 0.00 \\
\hline I (Brady) & $R L=-46.066714+4.522014 T-0.085514 T^{2}$ & 0.98 & 0.00 \\
\hline $\mathrm{R}$ & $R L=-48.282000+4.931000 T-0.098700 T^{2}$ & 0.99 & 0.00 \\
\hline $\mathrm{I}+\mathrm{R}$ & $\mathrm{RL}=-58.769429+5.832779 \mathrm{~T}-0.115979 \mathrm{~T}^{2}$ & 0.94 & 0.00 \\
\hline I+Azo & $R L=-64.853500+6.453350 T-0.129350 T^{2}$ & 0.90 & 0.00 \\
\hline $\mathrm{I}+\mathrm{Azo}+\mathrm{R}$ & $R L=-58.970143+5.924693 T-0.118693 T^{2}$ & 0.97 & 0.00 \\
\hline \multicolumn{4}{|c|}{ Total root length $\left(\mathrm{cm}^{-1}\right)$} \\
\hline $\mathrm{NI}$ & $T R L=-132.171143+12.479743 T-0.243443 T^{2}$ & 0.92 & 0.00 \\
\hline I (Brady) & $T R L=-137.716857+13.089257 \mathrm{~T}-0.256157 \mathrm{~T}^{2}$ & 0.94 & 0.00 \\
\hline $\mathrm{R}$ & $T R L=-113.917286+10.904186 \mathrm{~T}-0.212886 \mathrm{~T}^{2}$ & 0.96 & 0.00 \\
\hline $\mathrm{I}+\mathrm{R}$ & $T R L=-140.267786+13.285786 \mathrm{~T}-0.260186 \mathrm{~T}^{2}$ & 0.88 & 0.00 \\
\hline I+Azo & $T R L=-166.578000+16.097250 T-0.318550 T^{2}$ & 0.93 & 0.00 \\
\hline $\mathrm{I}+\mathrm{Azo}+\mathrm{R}$ & $T R L=-143.751357+14.196407 \mathrm{~T}-0.285307 \mathrm{~T}^{2}$ & 0.95 & 0.00 \\
\hline \multicolumn{4}{|c|}{ Root surfasse area $\left(\mathrm{cm}^{2}\right)$} \\
\hline $\mathrm{NI}$ & $\mathrm{RSA}=-33.494000+3.214850 \mathrm{~T}-0.062450 \mathrm{~T}^{2}$ & 0.90 & 0.00 \\
\hline I (Brady) & $\mathrm{RSA}=-33.506786+3.258586 \mathrm{~T}-0.063786 \mathrm{~T}^{2}$ & 0.97 & 0.00 \\
\hline $\mathrm{R}$ & $\mathrm{RSA}=-26.261786+2.612036 \mathrm{~T}-0.051436 \mathrm{~T}^{2}$ & 0.99 & 0.00 \\
\hline $\mathrm{I}+\mathrm{R}$ & $\mathrm{RSA}=-31.403714+3.044614 \mathrm{~T}-0.059514 \mathrm{~T}^{2}$ & 0.91 & 0.00 \\
\hline I+Azo & $\mathrm{RSA}=-38.567214+3.742414 \mathrm{~T}-0.073114 \mathrm{~T}^{2}$ & 0.82 & 0.00 \\
\hline $\mathrm{I}+\mathrm{Azo}+\mathrm{R}$ & $\mathrm{RSA}=-31.710143+3.176843 \mathrm{~T}-0.063343 \mathrm{~T}^{2}$ & 0.91 & 0.00 \\
\hline \multicolumn{4}{|c|}{ Root diameter (mm) } \\
\hline $\mathrm{NI}$ & $\mathrm{RD}=4.381143-0.277093 \mathrm{~T}+0.005393 \mathrm{~T}^{2}$ & 0.96 & 0.00 \\
\hline I (Brady) & $\mathrm{RD}=4.474143-0.281843 \mathrm{~T}+0.005443 \mathrm{~T}^{2}$ & 0.99 & 0.00 \\
\hline $\mathrm{R}$ & $\mathrm{RD}=3.435929-0.202929 \mathrm{~T}+0.004029 \mathrm{~T}^{2}$ & 0.98 & 0.00 \\
\hline $\mathrm{I}+\mathrm{R}$ & $\mathrm{RD}=3.505357-0.211157 \mathrm{~T}+0.004157 \mathrm{~T}^{2}$ & 0.92 & 0.00 \\
\hline I+Azo & $\mathrm{RD}=4.820929-0.320879 \mathrm{~T}+0.006279 \mathrm{~T}^{2}$ & 0.94 & 0.00 \\
\hline $\mathrm{I}+\mathrm{Azo}+\mathrm{R}$ & $\mathrm{RD}=4.345286-0.289686 \mathrm{~T}+0.005886 \mathrm{~T}^{2}$ & 0.98 & 0.00 \\
\hline \multicolumn{4}{|c|}{ Root volume $\left(\mathrm{cm}^{3}\right)$} \\
\hline $\mathrm{NI}$ & $R V=-0.598071+0.060071 T-0.001171 T^{2}$ & 0.91 & 0.00 \\
\hline I (Brady) & $R V=-0.594786+0.060586 T-0.001186 T^{2}$ & 0.99 & 0.00 \\
\hline $\mathrm{R}$ & $R V=-0.500500+0.051300 T-0.001000 T^{2}$ & 0.99 & 0.00 \\
\hline $\mathrm{I}+\mathrm{R}$ & $R V=-0.603571+0.060071 T-0.001171 T^{2}$ & 0.85 & 0.00 \\
\hline I+Azo & $R V=-0.647000+0.064650 T-0.001250 T^{2}$ & 0.75 & 0.00 \\
\hline $\mathrm{I}+\mathrm{Azo}+\mathrm{R}$ & $R V=-0.540857+0.056207 T-0.001107 T^{2}$ & 0.83 & 0.00 \\
\hline
\end{tabular}



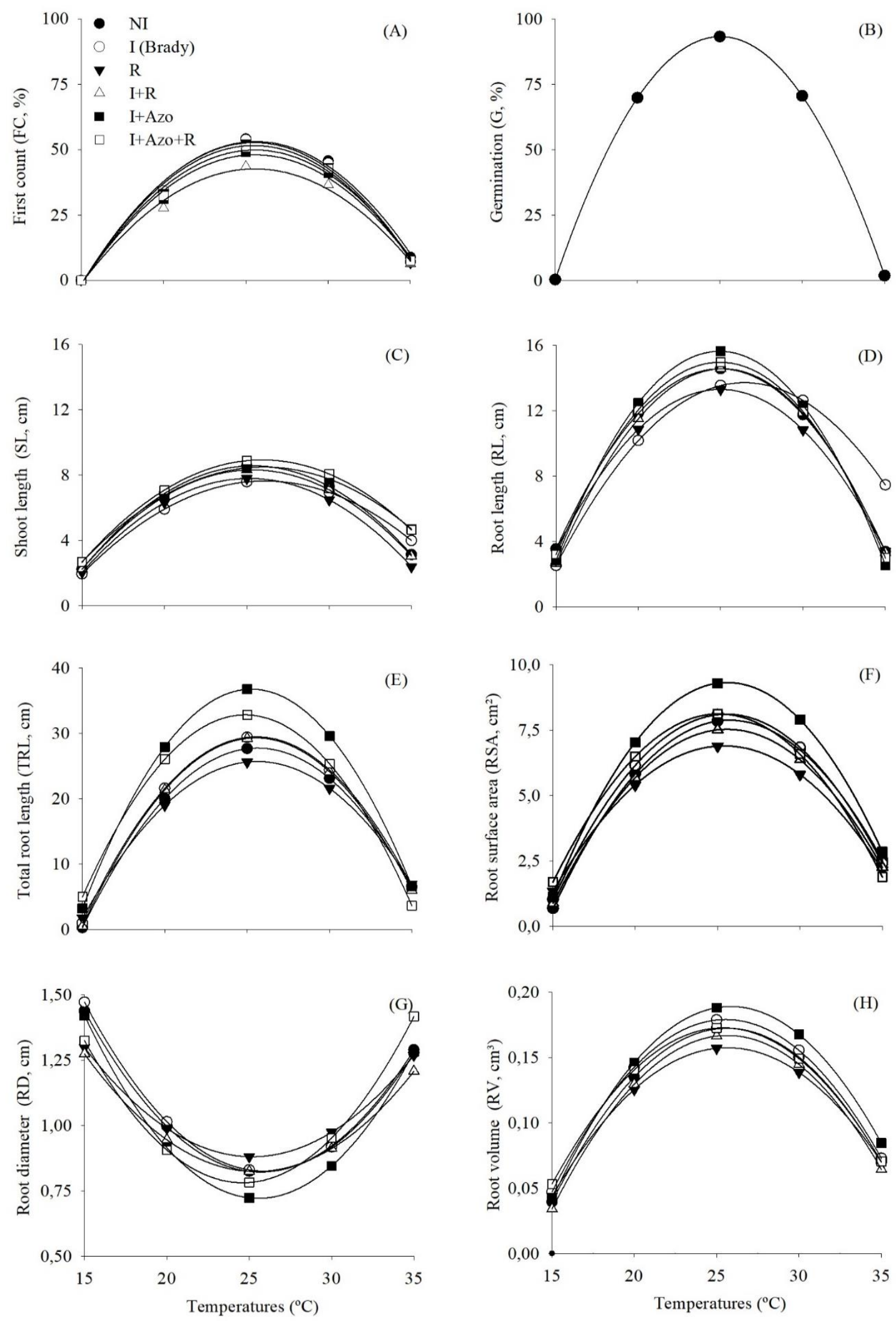

Fig 1. First count $(A)$, percentage of germination $(B)$, shoot length $(C)$, root length $(D)$, total root length (E), root surface area $(F)$, root diameter $(\mathrm{G})$ and root volume $(\mathrm{H})$, in response to the inoculations at the temperatures of 15, 2025,30 and 35으, Santa Maria, RS, Brazil. 
Table 2. Equations adjusted for the number of nodules, nodule dry mass, shoot dry mass, and root dry mass according to different inoculations and soil moisture. Santa Maria, RS, harvest 2015/2016.

\begin{tabular}{|c|c|c|c|}
\hline Treatment & Equation & $r^{2}$ & $p \leq 0.05$ \\
\hline \multicolumn{4}{|c|}{ Number of nodules (NN) } \\
\hline $\mathrm{NI}$ & $\mathrm{NN}=-366.220833+17.133340 \mathrm{U}-0.127551 \mathrm{U}^{2}$ & 0.92 & 0.00 \\
\hline $\mathrm{NI}+\mathrm{N}$ & $\mathrm{NN}=2.6$ & - & - \\
\hline I (Brady) & $\mathrm{NN}=-355.905000+16.569187 \mathrm{U}-0.122349 \mathrm{U}^{2}$ & 0.87 & 0.00 \\
\hline $\mathrm{R}$ & $\mathrm{NN}=-349.595000+16.315160 \mathrm{U}-0.119917 \mathrm{U}^{2}$ & 0.99 & 0.00 \\
\hline $\mathrm{I}+\mathrm{R}$ & $\mathrm{NN}=-342.780000+15.955507 \mathrm{U}-0.115549 \mathrm{U}^{2}$ & 0.92 & 0.00 \\
\hline I+Azo & $\mathrm{NN}=-305.574167+14.066993 \mathrm{U}-0.092617 \mathrm{U}^{2}$ & 0.93 & 0.00 \\
\hline $\mathrm{I}+\mathrm{Azo}+\mathrm{R}$ & $\mathrm{NN}=-307.032500+14.140327 \mathrm{U}-0.093551 \mathrm{U}^{2}$ & 0.96 & 0.00 \\
\hline \multicolumn{4}{|c|}{ Nodule dry mass ( NDM. mg) } \\
\hline $\mathrm{NI}$ & $\mathrm{NDM}=-366.220833+17.133340 \mathrm{U}-0.127551 \mathrm{U}^{2}$ & 0.82 & 0.00 \\
\hline $\mathrm{NI}+\mathrm{N}$ & $N D M=2.9$ & - & - \\
\hline I (Brady) & $N D M=-355.905000+16.569187 U-0.122349 U^{2}$ & 0.81 & 0.00 \\
\hline $\mathrm{R}$ & $N D M=-349.595000+16.315160 U-0.119917 U^{2}$ & 0.83 & 0.00 \\
\hline $\mathrm{I}+\mathrm{R}$ & $\mathrm{NDM}=-342.780000+15.955507 \mathrm{U}-0.115549 \mathrm{U}^{2}$ & 0.84 & 0.00 \\
\hline I+Azo & $N D M=-305.574167+14.066993 U-0.092617 U^{2}$ & 0.92 & 0.00 \\
\hline I+Azo+R & $\mathrm{NDM}=-307.032500+14.140327 \mathrm{U}-0.093551 \mathrm{U}^{2}$ & 0.91 & 0.00 \\
\hline \multicolumn{4}{|c|}{ Shoot dry mass (SDM. g) } \\
\hline $\mathrm{NI}$ & SDM $=-4.041667+0.252640 U-0.002048 U^{2}$ & 0.99 & 0.00 \\
\hline $\mathrm{NI}+\mathrm{N}$ & $S D M=-8.568333+0.474160 U-0.003675 U^{2}$ & 0.99 & 0.00 \\
\hline (Brady) & $S D M=-4.416667+0.272853 U-0.002197 U^{2}$ & 0.96 & 0.00 \\
\hline $\mathrm{R}$ & $S D M=-4.279167+0.255967 U-0.002012 U^{2}$ & 0.99 & 0.00 \\
\hline $\mathrm{I}+\mathrm{R}$ & $\mathrm{SDM}=-5.372500+0.313740 \mathrm{U}-0.002516 \mathrm{U}^{2}$ & 0.99 & 0.00 \\
\hline I+Azo & $S D M=-4.427500+0.264767 U-0.002060 U^{2}$ & 0.99 & 0.00 \\
\hline $\mathrm{I}+\mathrm{Azo}+\mathrm{R}$ & $\mathrm{SDM}=-4.473333+0.267227 \mathrm{U}-0.002080 \mathrm{U}^{2}$ & 0.96 & 0.00 \\
\hline \multicolumn{4}{|c|}{ Root dry mass (RDM. g) } \\
\hline Temperature & $\mathrm{RDM}=-1.012738+0.087468 \mathrm{U}-0.000698 \mathrm{U}^{2}$ & 0.99 & 0.00 \\
\hline
\end{tabular}
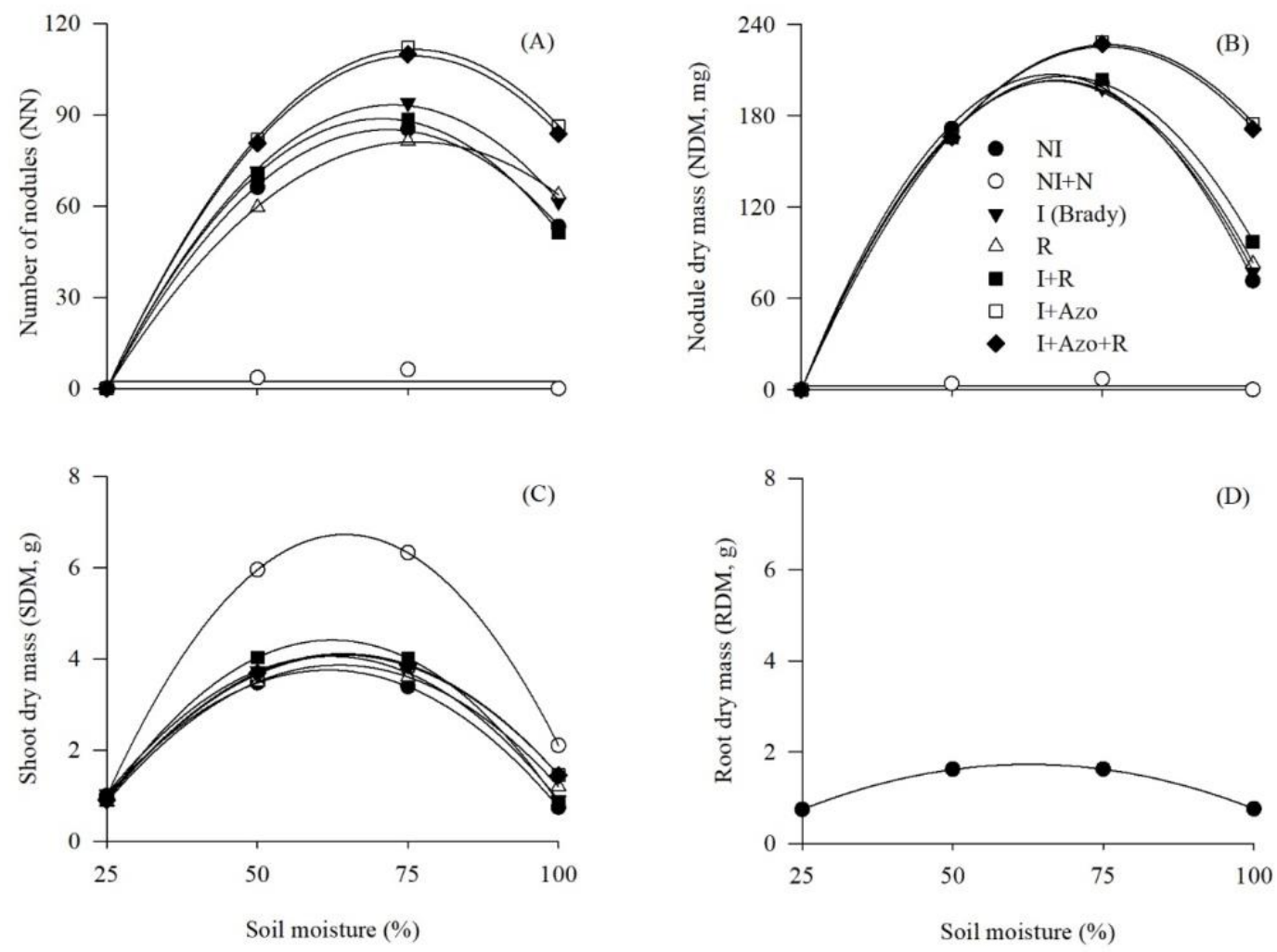

Fig 2. Number of nodules (A), nodule dry mass (B), shoot dry mass (C) and root dry mass (D) of the soil plants, in response to the soil inoculations with 25, 50, 75 and 100\% water retention capacity, in Santa Maria, RS, Brazil. 
number of infected points and the presence of fine roots are the main factors that govern the water and nutrient absorption (Hungria, 2000).

\section{Experiment 2 - greenhouse}

Experiment 2 revealed an interaction between inoculation and soil moisture for the variables analyzed $(P<0.05)$, whereas MSR was an exception.

This experiment revealed no significant differences for root dry mass (RDM). However, differences in number of nodules (NN) and nodules dry mass (NDM) could be confirmed using co-inoculation treatments (Figures $2 \mathrm{~A}, \mathrm{~B}$ ). According to Burdmann et al. (2000), the use of Azospirillum in soybean was confirmed to encourage lateral root emission, facilitating greater exploration of soil volume, enabling contacts to be established between the roots and the Bradyrhizobium bacteria, ensuring improved nodulation.

The co-inoculation increased the nodule number and the I+Azo treatment responded to this variable. Considering the inoculation with only Bradyrhizobium, the I+Azo coinoculation was statistically better than this treatment at humidity exceeding $70 \%$, raising the differences between these treatments by up to $100 \%$ humidity. The maximum technical efficiency was achieved at $76 \%$ humidity, in which a mean of 112 nodules per plant was produced. The treatment I+Azo was $20 \%$ superior compared to inoculation with Bradyrhizobium [ I (Brady)] which produced 93 nodules per plant, compared to the $\mathrm{NI}$ control which showed 85 nodules per plant growth at $31 \%$ of humidity.

The mineral $\mathrm{N}$ application decreased nodule formation compared with the other treatments, revealing only 2.5 nodules per plant on average, and no equation with a significant degree of adjustment. This shows that the addition of this nutrient in the mineral form is actually detrimental to nodule formation, besides incurring unnecessary expenditure. The mineral $\mathrm{N}$ application has shown inhibition of nodule formation, which may or may not resume during plant development (Hungria et al., 2007). The added $\mathrm{N}$ mineral has irreversibly inhibited the nitrogenase action in several diazotrophs and drastically minimized its activity below $10 \%$ of the initial efficiency, apart from inhibiting the nitrogenase synthesis (Reis and Teixeira, 2005). This is detrimental as it develops roots resistance to infection, suggesting that only new formed roots can be infected (Hungria et al., 2007). Thus, any factor that curtails the infection and formation of nodules will produce an irreversible reduction in these aspects because the time favorable for infection has already been lost.

At the moisture level of $25 \%$, nodule formation is absent due to the poor water availability. Water deficit based on the season and intensity compromises the bacterial survival (Santos et al., 2012). Besides restricting the formation and longevity of the nodules, water deficit may also inhibit the process of leghemoglobin synthesis which controls the oxygen $\left(\mathrm{O}_{2}\right)$ transport in specific quantities to the nitrogenase as it is sensitive to excess $\mathrm{O}_{2}$ (Taiz and Zieger, 2013).

The shoot dry mass (SDM) was increased in treatments nourished better with mineral $\mathrm{N}$. The $\mathrm{N}$ plays a crucial role in plant metabolism, influencing the synthesis of proteins and nucleic acids, and essential component of the chlorophyll molecule (Taiz and Zieger, 2013). However, plants revealing higher SDM will not necessarily produce greater yields. Zilli et al. (2010) reported higher SDM content in plants that were given $200 \mathrm{~kg} \mathrm{ha}^{-1} \mathrm{~N}$ compared with the Bradyrhizobium inoculation treatment. However, no statistical differences were observed for productivity.

The inoculations had no effect on the root dry mass (RDM), when the soil moisture levels alone were significant. By the adjusted equation, the highest root length (RL) values were observed at $62 \%$ humidity, producing $1.73 \mathrm{~g}$ of root per plant (Figure $2 \mathrm{D}$ ). This was the moisture content level at which the plant took the greatest advantage of the available water, because both water deficit and excess are detrimental. It was also around this humidity level that the plant demonstrated higher values for the number and dry mass of the nodules, reiterating that a good root system enhances soil volume exploration by the roots, and thereby greater area for Bradyrhizobium infection. Serafim et al. (2012), tested the potassium doses and soil moisture levels and reported that the most number of grains per pot was achieved at 59\% moisture, emphasizing that soil moisture at roughly $60 \%$ of the RL facilitates better plant development.

The higher RDM enables the plants to explore greater soil volume, boosting the water and nutrient absorption, causing greater nutrient accumulation in the aerial plant parts. This process promotes photosynthesis or the transformation of the captured solar energy into chemical energy to be accumulated later in the carbon frameworks. For this process to function effectively, it is must be ensured that the plants are not subjected to the effect of water stress. This will encourage the plants to absorb more sunlight, produce larger quantities of photoassimilates, and thus, provide more of these assimilates throughout the plant system (Taiz and Zieger, 2013).

\section{Materials and methods}

\section{Experiment 1 - seed Laboratory}

In 2016, the first experiment was performed at the Didactic and Seed Research Laboratory of the Phytotechnology Department of the Federal University of Santa Maria. We adopted a completely randomized design in a factorial $(6 \times 5)$ (inoculation $x$ temperatures, respectively) with four replications.

\section{Treatments}

The following inoculation treatments were included: non inoculation (NI); inoculation with Bradyrhizobium [I (Brady)]; root enhancers (R); inoculation with Bradyrhizobium + root enhancers $(I+R)$; co-inoculation with Bradyrhizobium + Azospirillum brasilense (I+Azo); co-inoculation with Bradyrhizobium + Azospirillum brasilense + root enhancers $(I+A z o+R)$. The temperatures of $15,20,25,30$ and $35^{\circ} \mathrm{C}$ were applied on seeds of Nidera 6209 RR cultivar.

The seeds were treated 24 hours prior to sowing with insecticide and fungicide using pyraclostrobin $25 \mathrm{~g} \mathrm{~L}^{-1}+$ methyl thiophanate $225 \mathrm{~g} \mathrm{~L}^{-1}+$ fipronil $250 \mathrm{~g} \mathrm{~L}^{-1}$ (Standak Top) in a dosage of $2 \mathrm{~mL} \mathrm{~kg}^{-1}$ of seed. 


\section{Inoculation}

The inoculation was done using Bradyrhizobium with a liquid inoculant that included $7 \times 10^{9}$ colony forming units (UFC mL ${ }^{1}$ commercial product) of the Bradyrhizobium japonicum strain CPAC 15 (semia 5079) and Bradyrhizobium diazoefficiens strain CPAC 7 (semia 5080), at a dose of $2 \mathrm{~mL}$ $\mathrm{kg}^{-1}$ of seed. For the treatments utilizing Azospirillum, a liquid inoculant that contained the $A$. brasilense strains $A b$ V5 and Ab-V 6 with guarantees of $2 \times 10^{8} \mathrm{CFU} \mathrm{\textrm {mL } ^ { - 1 }}$ in a dose of $2 \mathrm{~mL} \mathrm{~kg}^{-1}$ of seed was administered. The root enhancers was a product comprised of calcium (Ca) - $0.22 \mathrm{~g} \mathrm{~L}^{-1}$; sulfur (S) - $4.4 \mathrm{~g} \mathrm{~L}^{-1}$; molybdenum (Mo) - $5.5 \mathrm{~g} \mathrm{~L}^{-1}$; potassium (K2O) $2.2 \mathrm{~g} \mathrm{~L}^{-1}$ and zinc $(\mathrm{Zn}) 8.8 \mathrm{~g} \mathrm{~L}^{-1}$ in a dose of $2 \mathrm{~mL} \mathrm{~kg}^{-1}$ of seed. One hour prior to sowing, the seeds were inoculated and dried in the shade.

\section{Analyzed variables}

The seedlings were tested for first count (FC) and germination ( $G$ ) based on the Rules for Seed Analysis - RAS (Brasil, 2009), and the results were expressed as the mean percentage of the normal seedlings. Tests for the shoot length $(\mathrm{SL})$ and root length (RL) were carried out using methodology proposed by Nakagawa (1999), expressed as centimeters per seedling (Nakagawa, 1999).

To assess the morphological criteria of the root system, roots from four normal seedlings per replicate were taken from the seedling length test. The seedling roots from each treatment were carefully arranged without overlap on a small water slide, and digitized with an Epson $11000 \mathrm{XL}$ Scanner. The roots were then analyzed using the WINRHIZO PRO Software, determining the total root length (TRL), root surface area (RSA), root volume (RV) and root diameter (RD).

\section{Experiment 2 - greenhouse}

Experiment 2 was performed in an unheated greenhouse of the Biology Department of the Federal University of Santa Maria, from October 21 to December 5, 2016. Vessels containing $6 \mathrm{dm}^{3}$ of dry air substrate of Arsenic Red Dystrophic Argisol (EMBRAPA, 2013) were obtained and used from the São Pedro Mapping Unit. The soil from 0-20 cm depth was collected, shade dried and homogenized. The soil revealed the following chemical and physical features: $\mathrm{pH}$ in water - 5.5; MO - 2.6\%; clay - 26.0\%; P Mehlich 1 - $9.8 \mathrm{mg}$ $\mathrm{dm}^{3} ; \mathrm{K}-0.215 \mathrm{cmol} \mathrm{dm}{ }^{3}$; Ca $-5.9 \mathrm{cmolc} \mathrm{dm}^{3} ; \mathrm{Mg}-3.4 \mathrm{cmol}$ $\mathrm{dm}^{3} ; \mathrm{S}-12.9 \mathrm{mg} \mathrm{dm}{ }^{3} ; \mathrm{H}+\mathrm{Al}-3.1 \mathrm{cmolc} \mathrm{dm}^{3} ; \mathrm{CTC}-12.6 \mathrm{cmol}$ $/ \mathrm{dm}^{3}$; and $\mathrm{V} \%-75.4$.

A completely randomized experimental design, in a factorial [7 (seed inoculation treatments) $\times 4$ (humidity)] with three replications. The inoculation treatments were identical to those in experiment 1 , except for the inclusion of an uninoculated control with nitrogen supplied at a dose of 700 $\mathrm{mg} \mathrm{plant}^{-1}(\mathrm{NI}+\mathrm{N})$. Soil moisture levels were maintained at $25,50,75$ and $100 \%$ of the soil water retention capacity (WRC).

To ascertain the soil moisture levels, four replicates of oven dried soil $(100 \mathrm{~g}) \mathrm{kg}^{-1}$ at 65 으, were taken to the laboratory and placed in a funnel provided with a filter paper, after which $100 \mathrm{~mL}$ of water was poured in per repetition. Then 24 hours later, the soil was weighed. The upper limit of the soil water retention ( $100 \%$ of the retention capacity) was established from the difference between weights of the dry soil and wet soil. Next, the volume of water was adjusted for each moisture level by the soil mass in the vessels.

Only for the $\mathrm{N}+\mathrm{N}$ treatment, the $\mathrm{N}$ fertilization was applied by applying $700 \mathrm{mg} \mathrm{plant}^{-1}$, divided into four applications of $175 \mathrm{mg} \mathrm{plant}^{-1}$ per week (Campo and Hungria, 2007). The P was provided as triple superphosphate $(46 \% P)$, whereas the $\mathrm{K}$ was administered as potassium chloride $(60 \%)$, and $\mathrm{N}$ as urea (45\% N) (Novais et al., 1991).

The cultivar Nidera 6209 RR was sown on October 21, 2016. Ten seeds were sown equidistantly, per pot, at $3 \mathrm{~cm}$ depth. At the time of sowing, 50\% WCR level was provided to all the treatments, to ensure the emergence during the low and high moisture treatments. At 7 DAS, the plants were thinned until only four plants remained per pot. Humidity treatments were done at this point, adjusting the humidity every day by weighing the pots. Rotation was performed once every three days.

At 35 days after emergence (DAE), the variables listed were determined: shoot dry mass (SDM) (plants cut at the insertion point of the cotyledons), number of nodules (NN), nodule dry mass (NDM) and root dry mass (RDM). To assess the $\mathrm{NN}$, the plant roots occupying the entire vessel volume were first washed. Next, the nodules were counted after separating them from the roots. The collected materials (aerial parts, roots, nodules) were packed in paper bags and placed in a greenhouse, under forced air circulation at $60^{\circ} \mathrm{C}$ until constant mass was achieved. Finally, they were weighed in a $0.001 \mathrm{~g}$ precision scale.

The results were submitted to the assumptions of the mathematical model, and later to the analysis of variance by the $\mathrm{F}$ test. To compare the means of the qualitative variables, whenever significant, the Scott-Knott test was applied at 5\% of probability. The significant quantitative treatments were submitted to polynomial regression analysis. The SISVAR ${ }^{\circledR}$ (Ferreira, 2008) statistical software was used, while the Sigma Plot 12.5 software was used to draw the graphs.

\section{Conclusions}

The co-inoculation causes the soybean roots to increase in length, volume, surface area and diameter, particularly in the 20 to $30 \circ \mathrm{C}$ temperature range. It also significantly induces the nodule dry mass and nodule numbers to increase when the soil water retention capacity is between 56 and $96 \%$. The root enhancers practiced together with coinoculation reduced the root length and surface area.

\section{References}

Ashraf MA, Rasool M, Mirza MS (2011) Nitrogen fixation and índole acetic acid production potential of bacteria isolated from rhizosphere of sugarcane (Saccharum officinarum L.). Adv Biol Res. 5: 348-355

Bárbaro IM, Machado PC, Bárbaro Junior LS, Ticelli $M$, Bergantini Miguel F, Silva JAA (2009). Análise de cultivares de soja em resposta à inoculação e aplicação de cobalto e molibdênio. Ceres. 56: 342-349.

Brasil (2009) Regras para análise de sementes. Brasília, DF: Ministério da Agricultura, Pecuária e Abastecimento. 
Bulegon L, Klein J, Rampim L, Guimarães VF, Battistus AG, Kestring D, (2014) Desenvolvimento inicial de plântulas de soja inoculadas e co-inoculadas com Azospirillum brasilense e Bradyrhizobium japonicum. J Agron Crop Sci. 3: 26-37.

Burdmann S, Hamaoui B, Okon Y (2000) Improvement of legume crop yields by co-inoculation with Azospirillum and Rhizobium. The Otto Warburg Center for Agricultural Biotechnology. The Hebrew University of Jerusalem, Israel.

Campo RJ, Hungria M (2007) Protocolo para análise da qualidade e da eficiência agronômica de inoculantes, estirpes e outras tecnologias relacionadas ao processo de fixação biológica do nitrogênio em leguminosas. In: REUNIÃO DA REDE DE LABORATÓRIOS PARA RECOMENDAÇÃO, PADRONIZAÇÃO E DIFUSÃO DE TECNOLOGIAS DE INOCULANTES DE INTERESSE AGRÍCOLA, 13. Londrina, 2006. Anais. Londrina: Embrapa Soja. 89-123 (Documentos, 290).

Cerezini $P$, Kuwano $B H$, Santos $M B$, Terassi $F$, Hungria $M$, Nogueira MA, (2016) Strategies to promote early nodulation in soybean under drought. Field crops Research. 196: 160-167.

Cline WR (2007) Global Warming and Agriculture: Impact Estimates by Country. Center for Global Development/Peterson Institute for International Economics, Washington, DC, p. 187.

Christophe S, Jean-Christophe A, Annabelle L, Alain O, Marion P, Anne-Sophie V, (2011) Plant N fluxes and modulation by nitrogen, heat and water stresses: a review based on comparison of legumes and non-legume plants. In: Shanker, A., Venkateswarlu, B. (Eds.), Abiotic Stress in Plants - Mechanisms and Adaptations. Croatia.

Crozier A,Arruda P, Jasmim JM, Monteiro AM, Sandberg G, (1988) Analysis of indole-3-acetic acid and related indoles in culture medium from Azospirillum lipoferum and Azospirillum brasilense. Appl Environ Microbiol. 54: 28332837.

Empresa Brasileira De Pesquisa Agropecuária - EMBRAPA (2013) Sistema Brasileiro de Classificação de Solos. 3. ed. Brasília, 353p.

Fehr WR, Caviness CE (1977) Stages of soybean development. Ames: lowa State University, 12 p. (Special Report, 80).

Ferlini HA (2006) Co-Inoculación en Soja (Glicyne max) con Bradyrhizobium japonicum y Azospirillum brasilense. Articulos Técnicos - Agricultura.

Ferreira DF (2008) SISVAR: um programa para análises estatísticas e ensino de estatística. Revista Symposium, 6: 36-41.

González-Dugo V, Durand JL, Gastal F (2010) Water deficit and nitrogen nutrition of crops. A review. Agronomy for Sustainable Development. 30: 529-544.

Kloepper JW, Schroth MN (1978) Plant growth-promoting rhizobacteria on radishes. IV International Conference on Plant Pathogenic Bacteria. Angers France 2: 879-882.
Hungria M, Nogueira M A, Araujo RS (2015) Alternative methods of soybean inoculation to overcome adverse conditions at sowing. Afr J Agric Res. 10: 2329-2338.

Hungria M, Nogueira MA, Araujo RS (2013) Co-inoculation of soybeans and common beans with rhizobia and azospirilla: strategies to improve sustainability. Biol Fertil Soils. 49: 791-8013.

Hungria M, Campo RJ, Mendes IC (2007) A importância do processo de fixação biológica do nitrogênio para a cultura da soja: componente essencial para a competitividade do produto brasileiro. Londrina: Embrapa Soja. 80p. (Documentos, 283)

Nakagawa J (1999) Testes de vigor baseados no desempenho das plântulas. In: Krzyzanoski FC, Vieira RD, França Neto JB (Ed.). Vigor de sementes: conceitos e testes. ABRATES, 2.12.24.

Novais RF, Neves JCL, Barros NF (1991) Ensaio em ambiente controlado. In: Oliveira, A.J.; Garrido, W.E.; Araújo, J.D.; Lourenço, S. (Ed.). Métodos de Pesquisa em Fertilidade do Solo. Brasília: Embrapa-SEA. 189-253. (Documentos, 3).

Prado RM (2008) Nutrição de Plantas. São Paulo: Editora da UNESP. 407 p.

Reis VM, Teixeira KRS (2005) Fixação biológica do nitrogênio Estado da arte. In: Aquino AM, Assis RL, editores. Processos biológicos no sistema solo-planta: ferramentas para uma agricultura sustentável. Brasília: Embrapa Informação Tecnológica p.350-68.

Serafim ME, Ono FB, Zeviani WM, Novelino JO, Silva JV, (2012) Umidade do solo e doses de potássio na cultura da soja. Revista Ciência Agronômica 43: 222-227.

Silva TTA, Pinho ERV, Cardoso DL, Ferreira CA, Alvim PO, Costa AAF (2008) Qualidade fisiológica de sementes de milho na presença de bioestimulantes. Ciência e Agrotecnologia. 32: 840-846.

Smith CW (1995) Soybean (Glycine max [L.] Merrill), crop Production Evolution, History and Technology. 351-357.

Taiz L, Zieger E (2013) Fisiologia Vegetal, 5. ed. Porto Alegre: Artmed. 918p.

Tien TM, Gaskins MH, Hubbell DH (1979) Plant growth substances produced by Azospirillum brasilense and their effect on the growth of pearl millet (Pennisetum americanum L.). Appl Environ Microbiol. 37: 1016-1024.

Wang S, Wu H, Qiao J, Ma L, Liu J, Xia Y, Gao X, (2009) Molecular mechanism of plant growth promotion and induced systemic resistance to tobacco mosaic virus by Bacillus spp. J Microbiol Biotechnol. 19: 1250-1258.

Zilli JE, Campo RJ, Hungria M (2010) Eficácia da inoculação de Bradyrhizobium em pré-semeadura da soja. Pesquisa Agropecuária Brasileira.45: 335-338.

Zilli JE, Marson LC, Campo RJ, Gianluppi V, Hungria M, (2006). Avaliação da fixação biológica de nitrogênio na soja em áreas de primeiro cultivo no cerrado de Roraima. Embrapa, 9p.

Zullu JR J, Pinto HS, Assa ED (2008) Potenciais impactos econômicos do aquecimento global em duas commodities brasileiras de acordo com prognósticos do IFCC. Terrae. 3, p. 28-39. 